\title{
A Study on Zeng Hu's Translation of The Thorn Birds from the Perspective of Chesterman's Norm Theory
}

\author{
Chengyi Ma \\ School of Foreign Studies, Nanjing University, China
}

\begin{abstract}
Based on the norm theory of Toury and Hermans, Chesterman makes a further development on the study of translation norms. In his theory, translation norms fall into two categories: expectancy norms and professional norms. Expectancy norms are from the expectations of target readers and influenced by the economic, political and cultural factors of the target society. Professional norms manipulate the translation process and are subject to expectancy norms. Professional norms can be further divided into accountability norms, communication norms and relation norms. Chesterman's norm theory covers the ethical, social and skill norms during the whole translation process, which has great significance for translation studies and practice. The author of this paper has conducted an overall study on The Thorn Birds translated by Zeng Hu from the perspective of Chesterman's norm theory, aiming to analyze the translator's conformity to these norms and how these norms influence his translation. It can be concluded that translation is a norm-governed activity. During the translation of The Thorn Birds, the translator Zeng Hu has, in his own way, ingeniously conformed to the translation norms by Chesterman: he not only conforms to the expectancy norms by adopting different translation strategies and styles according to the target readers' needs, but also applies professional norms to make his translation work well accepted by readers and enjoy lasting popularity. Thus, it can be seen that the instructional and normative effects of translation norms is of vital importance to the success of a translation.
\end{abstract}

Index Terms-The Thorn Birds, expectancy norms, accountability norms, communication norms, relation norms

\section{INTRODUCTION}

Norm is a key concept in descriptive translation studies and an effective tool for the analysis of translation phenomena. The norm theory by Chesterman provides a systematical and historical perspective to analyze both translation product and process, which is a significant development in descriptive translation studies.

The Thorn Birds is an English novel by the well-known Australian author Colleen McCullough. Since its publication, this novel has won great popularity among readers and is praised as the Australian version of Gone with the Wind. The famous Chinese translator Zeng Hu spent nearly ten years translating this novel into Chinese and revising it over and over until it was finalized in 1989. His translation version is greatly welcomed by Chinese readers due to its high quality.

Many scholars in China have studied Zeng Hu's translation of The Thorn Birds from different angles, but none from the angle of Chesterman's norm theory. So the author attempts to conduct a systematic and deep analysis on Zeng's translated version of The Thorn Birds from the perspective of Chesterman's norm theory, aiming to analyze the translator's conformity to translation norms and how these norms influence his translation.

\section{Chesterman's Norm THEORY}

\section{A. Expectancy Norms}

Expectancy norms, corresponding to the product norms in sociology, are target readers' expectations of a translation (of a given type) about what a translation (of this type) should be like (Chesterman, 1997). Target readers are not passive receptors of a translation. Rather they influence a translation product from aspects of text type, style and register, lexical choices and so on. To a certain extent, the expectations of target readers should be a standard of translation.

These expectations developed partly because of the prevailing translation tradition in the target culture, and partly because of the form of a similar text type in the target language. Besides, they can be influenced by the economic, political and cultural factors of the target society (Chesterman, 1997).

Chesterman's expectancy norms have provided a comprehensive way to evaluate and compare translation works as well as to describe and explain translation phenomena. At a given time and in a given culture, the more closely a translator conforms to readers' expectancy, the more popular his or her work will be.

\section{B. Professional Norms}


Professional norms are actually "process norms" in sociology, which regulate the whole process of translation, including the translation methods and strategies used during translation process. Chesterman subsumed all professional norms under three general high-order norms: accountability norms, communication norms and relation norms.

(a) Accountability norms: They refer to a translator's responsibility to relevant parties of translation, including the original author, the potential readers and so on. It is an ethical norm, for translators are supposed to be appropriately loyal to these parties mentioned above. In case of conflict among different parties, translators are allowed to have their own choices about which party should be given the primary loyalty.

(b) Communication Norms: Translation is not just about language, but also has its certain communicative function. So the communication norm requires translators to optimize communication between all the parties involved in a given situation. Under this social norm, a translator functions as a communication expert, who mediates the intentions of others and also plays a role as a speaker of his or her own

(c) Relation Norms: This is a linguistic norm. Translators are supposed to set up and maintain a proper relation of similarity between source text and target text.

As for relations between texts, there's a wide variety of them. To decide what kind of relation is proper in a given situation, translators should refer to the type of text, demands of the commissioner and so on (Chesterman, 1997).

\section{Case Study on The Thorn Birds Translated By Zeng Hu}

As translation is a norm-governed activity (Han, 2004a), any translation phenomena can be partly explained by norms. Therefore, in this section, The Thorn Birds translated by Zeng Hu will be analyzed under the framework of Chesterman's norm theory. The author of this paper aims to find out how Zeng Hu's translation has conformed to Chesterman's norm theory and how these norms have influenced his translation so that an overall understanding of Zeng's translation of this novel can be got.

\section{A. Expectancy Norms in Zeng's Translation of The Thorn Birds}

Zeng Hu finalized his translation of The Thorn Birds in 1989. It had been over 10 years since the policy of reform and opening up was implemented. China's door was opened to the outside world, which resulted in great changes in various fields. There's more and more frequent communication between China and the rest of the world in the fields of politics, economics, culture and so on. China was gradually becoming globalized. In the aspect of culture, lots of foreign literature works were introduced and translated. People were eager to know the outside world and learn about foreign cultures from all aspects. What's more, with the enhancement of people's education level, their cultural taste also improved and their horizon broadened. People's mind were advanced and open, which made foreign cultural elements were easy to be accepted.

Against such social background, people's expectations towards translated literature works can be easily got. That is to learn about foreign culture as much as possible. So in Zeng's translation of The Thorn Birds, the translator fully displays the exotic scenery and adequately exposes readers to foreign culture, which can be seen in the following examples:

Example 1:

“......steam gushed howling out of cracks in the sides of innocent hills, volcanoes summed smoke into the sky and the alpine streams ran warm. Huge lakes of mud boiled oilily, the seas lapped uncertainly at cliffs which might not be there to greet the next incoming tide, and in places the earth's crust was only nine hundred feet thick. " (McCullough, 2007, p.6)

“在那无害的山峰边缘的裂缝里, 蒸汽咆哮着奔涌而出, 火山的浓烟直抵云天, 山间的河川淌着热气腾腾的水 流。巨大的泥浆湖油锅似地沸腾着。海水神出鬼没地拍击着悬崖峭壁, 当下一个浪潮席卷而来的时候, 这些峭 壁或许已经不复存在, 而不能前来迎候了。在某些地方, 地壳表面的厚度只有 900 英尺。” (Zeng,2008,p.4)

Example 2:

"Kangaroos in flocks of thousands streamed leaping through the trees, taking fences in their stride, utterly lovely in their grace and freedom and numbers; emus built their nests 96 in the middle of the grassy plain and stalked like giants about their territorial boundaries, taking fright at anything strange and running fleeter than horses away from their dark-green, football-sized eggs; termites built rusty towers like miniature skyscrapers; huge ants with a savage bite poured in rivers down mounded holes in the ground.” (McCullough, 2007, p.80)

“成群结队的袋鼠蹦蹦跳跳、络绎不绝地穿过树林, 不费吹灰之力地越过篱栅; 它们那种优雅健美、自由自在 之态以及数量之多, 使人心旷神怡。鸸鹋在平展展的草地中筑巢, 像巨人一样在它们的领地里高视阔步; 任何 陌生的东西都会使它们大吃一惊, 一溜烟地从它们那深绿色的、足球大小的蛋旁飞逃而去, 比马还跑得快。白 蚁构筑的棕色的蚁冢是小小的摩天大楼; 咬啮东西极其凶猛的巨蚁源源不断地顺河而下, 在地下营造洞穴。” (Zeng, 2008, p.70)

The first example is a brief description of the natural environment in New Zealand, which shows readers the living environment of the Cleary family as well as the unique scenery of New Zealand. While the second example is a short depiction of Drogheda in Australia, where the Cleary family later moved to. Actually, there is a large number of such detailed depictions of natural scenery in the original text.

Instead of omission, Zeng Hu faithfully translated all of them. His graceful language successfully leads readers into 
the exotic world and shows them the life of people in New Zealand and Australia from the beginning of 20th century to the end of the 1960s. This greatly meets readers' demands and expectations of foreign culture and gains their preference.

Zeng's preservation of exotic culture was embodied not only by the translation of scenery depictions, but also by the translation of names. The following table contains the names of the main characters in the novel and their translation.

Example 3:

\begin{tabular}{|l|l|}
\hline Names & Translation \\
\hline Meghann “Meggie” Cleary & 梅吉·克利里 \\
\hline Ralph de Bricassart & 拉尔夫·德·布里克萨特 \\
\hline Padraic “Paddy” Cleary & 帕迪·克利里 \\
\hline Luke O’Neill & 卢克·奥尼尔 \\
\hline Fiona “Fee” Armstrong Cleary & 菲奥娜·阿姆斯特朗·克利里 \\
\hline Dane O'Neill & 戴恩·奥尼尔 \\
\hline Justine O'Neill & 朱丝婷·奥尼尔 \\
\hline
\end{tabular}

It can be seen from the above table that the translator adopts transliteration to deal with the English names in the original text. The characteristics of English names are presented and readers can thus learn about the form and feature of foreign names. In this way, the translator makes his work more acceptable and more popular.

What's more, readers tend to favor translations that are learnable and understandable. Due to the language difference between English and Chinese, sometimes translating according to the sentence structure of the original text may make readers confused. Chinese features the four-character structure, which has a beauty of phonology. Chinese readers are used to this kind of expression for they are short and pithy. In The Thorn Birds translated by Zeng Hu, the translator attaches great importance to this point and uses the four-character structure to meet readers' expectation.

Example 4:

“He looked sincere, upset, anxious, contrite. And very like Ralph de Bricassart." (McCullough, 2007, p.291)

“他看上去显得很诚恳, 心烦意乱, 焦急如焚, 追悔莫及, 和拉尔夫.德.布里克萨特十分相像。” (Zeng, 2008, p.255)

Example 5:

"It was like having a ticket of admission to a whole new planet, peering through the glass down into that teeming, exquisitely fragile world, where delicate forms were buoyed and bolstered by the loving intimacy of water."(McCullough, 2007, p.323).

“透过玻璃钢看着下面那千姿万态、精巧优美、脆而易碎的世界, 就好象买门票进入了一个耳目一新的陌生的 星球。令人神爽、亲切宜人的海水中漂浮着各种精美优雅的生物。” (Zeng, 2008, p.283)

Example 6:

"She had hoped to see the only girl married on Drogheda with flags flying and cymbals clashing, days of celebration.”(McCullough, 2007, p. 261)

“她本来希望在德罗海达唯一的姑娘结婚之时, 能看到彩旗飞扬, 锣鼓喧天, 狂欢数日的场面。” (Zeng,2008,p.227)

As can be seen from the above examples, the translator fully uses the four-character structures in Chinese. The meaning and style of the original text are vividly and accurately conveyed to readers with concise and rhythmic expressions. This helps to increase the literary elegance of the writing as well as makes the text easy for the target readers' reading.

In a word, in this work, the translator satisfies readers' requirements and expectations in different ways, including remaining the exotic flavor of the original text and using Chinese four-character structures. And this conformity to expectancy norms makes his work popular among more and more people.

\section{B. Accountability Norms in Zeng's Translation of The Thorn Birds}

According to Chesterman, the value behind accountability norms is trust (Han, 2004b). First of all, a translator should trust the author of the original text and that the original work is worth translating. Then, others should also trust the proficiency of a translator and believe he or she is capable of translating the work. Meanwhile, the translator should undertake the responsibility, make efforts to translate the work well and establish his or her reputation as a translator.

In the case of The Thorn Birds, the translator conforms to the accountability norms very well. Undoubtedly, Zeng Hu trusts the original novel and its author Colleen McCullough, for he chooses this novel to translate. This can also been seen from the preface of the Chinese version of this novel. In the preface, detailed introduction as well as high remarks about the original work are presented. "In a word, The Thorn Birds is a rare best-selling novel with well-knit structure as well as fluent and vivid language. It is full of passion and poetic flavor, with epigrammatic words scattering in the whole text. The Thorn Birds is a very readable novel. I'd like to recommend it to any literate person (Zeng, 2008)."

Meanwhile, Zeng $\mathrm{Hu}$ shows his responsibility as a good translator through the repeated revision of his translation. The first draft was finished in 1980, after which he revised twice until 1989. The whole translation process went through almost 10 years. However, in his epilogue, Zeng Hu said that there still might be some defects in his translation. Such rigorous scholarship is exactly a manifestation of the translator's conformity to accountability norms. 


\section{Communication Norms in Zeng's Translation of The Thorn Birds}

Communication norms emphasize a translator's responsibility to maximize communication between all the parties involved in a given situation of translation. The value governs the communication norms is understanding (Han, 2004b: 47). The aim of communication is to change non-understanding to understanding and avoid misunderstanding. Here, the author of this paper mainly focuses on the communication between the original novel and the target readers via translation.

One embodiment of Zeng Hu's conformity to communication norms is his use of footnotes. Due to cultural differences, there are inevitably some "cultural barriers" existing during the translation process. Some source-culture-bound features in the original text may cause difficulties for target readers' comprehension and thus lead to misunderstanding. So translators ought to remove or at least weaken the cultural barriers assuming that the target readers don't have the cultural knowledge of the source text. Adding footnotes is a good way to explain and make clear the contents. There are totally 189 items of footnote in Zeng's translation. The followings are some examples:

Example 7:

"I'm not gifted with Promethean foresight, and emotional involvement makes one a poor judge." (McCullough, 2007, p.364).

“我没有普罗米修斯那样的先见之明，卷进狂热之中使一个人的判断力极低。” (Zeng, 2008, p.320)

“注: 希腊神话中的神祇, 因把天火偷给人类而受到了宙斯的惩罚, 被锁在高加索的悬崖上, 每天有一只鹑鹰 啄食他的肝脏, 然而他的肝脏旋即长成, 直到有人自愿替他受罪为止。” (Zeng,2008,p.320)

Promethean is from the word "Prometheus". Prometheus is a character in Greek mythology, who was the creator of mankind. However, Chinese readers may know little about Prometheus and thus may feel confused about the meaning of the sentences in discussion. To help readers figure it out, Zeng Hu adds a footnote to introduce some background information of Prometheus and the communication between the original text and readers is successfully achieved.

Example 8:

“In the days before the Fall, it is said Eve didn't menstruate." (McCullough, 2007, p.135)

“在亚当犯原罪以前的时代里，据说夏娃是不行经的。” (Zeng, 2008, p.119)

“注：《圣经. 创世纪》称, 亚当是上帝用泥土造的第一个男人, 上帝又用亚当的肋骨造出其妻夏娃, 同置于“伊 甸园” 中。后因两人同时吃了禁果, 遂相爱, 被逐出 “伊甸园”。此后, 作为亚当与夏娃后代的人类便有了与生俱 来的男女之爱，基督教称此为原罪。”(Zeng, 2008, p.119)

The story of Eve and Adam is recorded in the Bible. It's the western version about human being's origin. Chinese readers may be unfamiliar with it. So the addition of this footnote is helpful for readers to understand the text. Meanwhile, readers' needs for exotic flavor and foreign atmosphere are met by translator's preservation of foreign cultural characteristics. Their horizon is also widened by being directly exposed to foreign culture.

Another embodiment of the translator's conformity to communication norms is his application of domestication strategies during translation process. Although readers expect exotic color, foreignization can't be brought to extreme. Otherwise, it may cause over-foreignization and make readers confused. In this translated work, to make readers easily understand the text, the translator in some cases render English expressions into Chinese idiomatic expressions to express the same meaning as the original text. Let's look at the following examples:

Example 9:

"She shook her head, laughed. What's the use? It's like talking to a brick wall." (McCullough, 2007, p.351)

“她摇摇头, 大笑起来, 这有什么用? 就像是在对牛弹琴。” (Zeng, 2008, p.309)

"Be like talking to a brick wall"is an English idiom. If talking to someone is like talking to a brick wall, the person you're speaking to doesn't listen, which makes you have a feeling of wasting time and energy. However, Chinese readers do not have this expression habit. As a mediator in translation, the translator Zeng Hu translates this phrase to “对牛弹 琴”, which is a Chinese idiom having the same meaning as "talking to a brick wall”. Thus, readers can get the meaning immediately and achieve communication with the original text. The followings are other such examples:

Example 10:

"No chance of that, I'm afraid..." (McCullough, 2007, p.58)

“我恐怕没这个造化...” (Zeng, 2008,p.50)

Example 11:

"Well, let's cross that bridge when we come to it, eh?" (McCullough, 2007, p.275)

“唔, 船到桥头自然直, 好吗?” (Zeng, 2008, p.240)

Example 12:

"We're supposed to lick her boots." (McCullough, 2007, p.31)

“她认为我们该舔她的靴子、拍她的马屁的。” (Zeng, 2008, p.26)

Example 13:

“Admit it, Luke, you're a miser." (McCullough, 2007, p.143)

“承认吧, 卢克, 你是个守财奴。” (Zeng, 2008, p.309)

Example 14: 
“Lord help us, it's herself! the maid said clearly from the reception room opposite .”(McCullough, 2007, p.141)

“老天爷呀，是她！女仆的说话声从对面的客厅里清晰地传了过来。”(Zeng, 2008, p.124)

It’s obvious that such kind of words and phrases like “造化”, “船到桥头自然直”, “拍马屁”, “守财奴”, “老天爷” are typical Chinese expressions. It's easy to translate the above English sentences into Chinese. But it's difficult to make these translations impressive. If the translator just renders these sentences literally, it may be rigid and hard for readers to understand. By such an ingenious translation, Zeng Hu accurately keeps the original meaning without retaining the original expressions. Most importantly, these words and phrases with Chinese cultural characteristics are easy for readers to understand and win their acceptance.

From the above analysis, it can be seen that in order to prompt target readers' understanding of the original text and realize the optimal communication, the translator not only adds footnotes to make explanations to readers and bring them exotic culture, but also adopts the strategy of domestication to close the distance between readers and the original text. The aim of communication is well achieved in his translation.

\section{Relation Norms in Zeng's Translation of The Thorn Birds}

Here, the author of this paper mainly focuses on the influence of text types on the translator's conformity to relation norms.

According to the famous translation Theorist Peter Newmark, source language texts can be divided into six types based on their functions. They're respectively expressive texts, informative texts, vocative texts, phatic texts, aesthetic texts and metalingual texts (Zhang, 2014). Different from other literary works, a novel contains various text types to serve for the development of plot.

So is the case of The Thorn Birds. Large numbers of dialogues between characters and depictions of the environment as well as figures are presented in the novel. Besides, testament, news, cable and speech are also contained. So it can be seen that the major text of this novel is expressive text, while the informative text and vocative text occupy a small part of it.

In the following parts, the translator's conformity to relation norms in translating these three text types will be analyzed respectively.

1. Relation Norms in Translating Expressive Texts

In The Thorn Birds, there are a lot of descriptions of natural environment, the characters and the conversations between figures, which are all expressive texts. They aim to not only bring some information or facts to readers, but also more importantly, to bring a certain emotion or feeling to them and depict the characters' personalities. Thus, in translating expressive texts, translators are supposed to explore the intention of the original texts and maintain a proper similarity with the original text in style and meaning. Here come some examples:

Example 15:

"It had been a dry winter, and the summer rains didn't come. Knee-high and lush, the tawny grass dried out in the stark sun until even the inner core of each blade was crisp. To look across the paddocks required slitted eyes and a hat brim drawn far down on the forehead." (McCullough, 2007, p.190).

“冬天干旱, 夏天就没有雨水。茂盛的、没膝高的草在炎炎赤日的照射下变成了茶褐色, 甚至连叶片心都蒸了。 要想放眼瞭望一下牧场, 就得眯起眼睛, 把帽洞低低地压在前额上。”(Zeng,2008,p.168)

This paragraph describes the natural scenery of Australia in winter. The writer uses the words like "dried out" "stark" "crisp" "slitted eyes" and so on to show the dry climate and lack of vitality. In the Chinese version of this paragraph, “dried out” is not literally translated into “干枯”. Rather, it is rendered into “变成了茶褐色”, which vividly presents the image before readers and makes them feel the aridity of winter in Drogheda. Thus this free translation successfully gets the effect of the original text. Meanwhile, for other words "stark" "crisp" and "slitted eyes", Zeng Hu translated them respectively into “炎炎赤日”“焉了”“眯着眼睛”. These detailed and vivid translations accurately convey the style of the original text and thus maintain a similarity as it.

2. Relation Norms in Translating Informative Texts

In translating expressive texts, language and writing styles are the focus; while for the translation of informative texts, content and information should be emphasized. In The Thorn Birds, informative texts include testament, news, cable and logbook. Here comes an example:

Example 16:

"Born on September 23, 1893, in the Republic of Ireland, Cardinal de Bricassart was the second son of a family which can trace its descent from Baron Ranulf de Bricassart, who came to England in the train of William the Conqueror. By tradition, Cardinal de Bricassart espoused the Church. He entered the seminary at the age of seventeen, and upon his ordination was sent to Australia. His first months were spent in the service of the late Bishop Michael Clabby, in the Diocese of Winnemurra." (McCullough, 2007, p. 411)

“德·布里克萨特红衣主教于 1893 年 9 月 23 日生于爱尔兰共和国, 是一个血统可以追溯到拉诺夫·德. 布里克萨 特的家庭的次子。这个家族是随征服者威廉一世的队伍到了英国来的。根据传统, 德. 布里克萨特红衣主教加入 了教会。他在 17 岁时进入神学院, 受委任派至澳大利亚。最初几个月, 他在温尼穆拉的迪奥西斯为前主教迈克 尔·克莱比服务。”(Zeng, 2008, p.363) 
This extract is a part of a piece of news on newspaper from the novel, which introduces the Father Ralph. The intention of the news is to provide some information about Ralph and let readers of the newspaper know about him. The language of the original text is plain, direct and easy to understand. So in the translated version, the translator also adopts literal translation and renders all the detailed information into simple words. Therefore, it can be seen that in translating informative texts, translators are supposed to pay more attention to the completeness of information than to the polish of language.

3. Relation Norms in Translating Vocative Texts

Vocative texts aim to appeal to or encourage receivers to do something. So the language of vocative texts is inspiring, persuasive and infectious. Such texts include notices, speeches, propaganda and so on (Zhang, 2014). The following is an example of vocative text in The Thorn Birds.

Example 17:

"Our staying power, and that of the Mother Country, will be best assisted by keeping our production going, continuing our avocations and business, maintaining employment, and with it, our strength. I know that in spite of the emotions we are feeling, Australia is ready to see it through.” (McCullough, 2007, p.368)

“我们赖以支持的那个政权, 亦即我们的祖先之邦, 将通过我们生产的继续进行, 我们以副业和商业的继续进 行和保证就业——这就是我们的力量——得到最好的援助。我知道, 无论我们现在正在体验着什么样的感情, 澳 大利亚已准备把战争进行到底。” (Zeng,2008,p.323)

The above example is a part of the speech by the PM of Australia on the radio. This political speech is addressed to stimulate listeners' fighting will and encourage them to join the Second World War to fight against the Hitler. In the original text, words like "mother country" and "be ready" are used to create a kind of inspiring atmosphere. So in the translated version, the translator is not only faithful to the meaning of the source text, but also recreate the original feeling for target readers, which is shown from the expressions “祖先之邦”, “进行到底” and so on. This is the way in which the translator retains similarity with the original text.

From the above analysis, it can be seen that even in a literary work, there are different text types. During his translation, the translator Zeng $\mathrm{Hu}$ conforms to the relation norms in different ways according to different text types, which makes his translation more readable and close to the original text. Thus the same feeling gained by the original readers can be brought to the target readers.

\section{CONCLUSION}

Based on Chesterman's norm theory, the author of this paper has conducted an overall study of The Thorn Birds translated by Zeng Hu. Through the detailed analysis of examples, it can be found that during his translation, the translator has in his own way conformed to the norms in Chesterman's theory. For expectancy norms, the translator Zeng $\mathrm{Hu}$ takes the social background and readers' needs into account during his translation process, bringing exotic flavor into his translation work and making it easy for people to understand. Under the accountability norms, he revises his translation again and again and makes great efforts to offer readers a good work. Besides, he also adopts various translation strategies and methods to flexibly meet requirements of relation norms and communication norms, which helps his work win preference of readers. Thus it can be concluded that the translator's conformity to these norms plays an important role in his success of translation.

\section{REFERENCES}

[1] Chesterman, A. (1997). Memes of Translation. Amsterdam and Philadelphia: John Benjamins.

[2] Colleen, M. (2007). The Thorn Birds. London: Virago Press.

[3] Colleen.M. (2008). The Thorn Birds. (Zeng Hu, Trans). Nanjing: Yiling Press.

[4] Fu Lei. (2015). A Comparative Study of Two Chinese Versions of The Thorn Birds from the Perspective of Toury's Norm Theory. Hefei: Hefei University of Technology.

[5] Han Jianghong. (2004a). On China's Studies of Translational Norms. Shandong Foreign Language Teaching Journal, (6): 69-72.

[6] Han Jianghong. (2004b). Chesterman's Theory of Translational Norms. Foreign Languages Research, (2): 44-47, 56.

[7] Han Jianghong. (2012). An Introduction to Contemporary Western Translation Theories. Nanjing: Nanjing University Press.

[8] Li Dechao, Deng Jing. (2004). Chesterman's Translation Norms: The Transcendence of Traditional Translation Concepts. Journal of Foreign Languages, (04): 68-75.

[9] Shi Juanzhi. (2011). Multiple Roles of the Translator Perceived from Reception Aesthetics. Hunan: Xiangtan University.

[10] Zhang Juan. (2014). Translation Strategies of The Thorn Birds from the Perspective of Peter Newmark's Translation Theory. Hebei: Hebei United University.

[11] Zheng Jia, Zhang Yu. (2011). Chesterman's Translation Norms and Yan Fu's Translation of Evolution and Ethics. Central China Normal University Journal of Postgraduates, (03): 109-112. 
Chengyi Ma was born in Shanxi, China in 1995. She received her bachelor's degree in English literature from Shanxi Normal University, China in July, 2017.

She is currently a postgraduate in the School of Foreign Studies, Nanjing University, Nanjing, China. Her major is English Translation. Ms. Ma has obtained the certificate of ETTBL (advanced-level translator and advanced-level interpreter) and passed CATTI (English Translation: preliminary). 